\title{
INHIBITORY EFFECT OF ESSENTIAL OILS AGAINST TRICHOSPORON OVOIDES CAUSING PIEDRA HAIR INFECTION
}

\author{
Seema Saxena $^{1^{*}}$, Veena Uniyal ${ }^{2}$, R.P.Bhatt ${ }^{2}$ \\ ${ }^{1}$ Department of Botany, SGRR (PG) College, Pathribagh, Dehradun, 248001; ${ }^{2}$ Department of Botany, HNB Garhwal University, \\ Srinagar Garhwal, 246174.
}

Submitted: September 24, 2011; Returned to authors for corrections: December 16, 2011; Approved: June 07, 2012.

\begin{abstract}
Piedra, is an asymptomatic fungal infection of the hair shaft, resulting in the formation of nodules of different hardness on the infected hair. The infection also known as Trichomycosis nodularis is a superficial fungal infection arising from the pathogen being restricted to the stratum corneum with little or no tissue reaction. The nodules are a concretion of hyphae and fruiting bodies of the fungus. Two varieties of Piedra may be seen, Black Piedra and White Piedra. The fungus Trichosporon ovoides is involved in the occurrence of both types of Piedras. The purpose of this study was to examine the effectiveness of selected essential oils for the control of growth of the fungus and to determine whether the antifungal effect was due to the major compounds of the oils. Two screening methods viz. Agar well diffusion assay and Minimum Inhibitory Concentration were adopted for the study. MIC and MFC were determined by tube dilution method. Essential oils from Eucalyptus, Ocimum basilicum, Mentha piperita, Cymbopogon flexuosus, Cymbopogon winterians, Trachyspermum ammi, Zingiber officinalis, Citrus limon, Cinnamomon zeylanicum, Salvia sclarea, Citrus aurantifolia, Melaleuca alternifolia, Citrus aurantium, Citrus bergamia, Pogostemon pathchouli, Cedrus atlantica, Jasminum officinale, Juniperus communis, Abelmoschus moschatus, Cyperus scariosus, Palargonium graveolens, Boswellia carterii, Rosa damascene, Veteveria zizanoides and Commiphora myrrha were evaluated. The essential oils of Cymbopogon winterians, Mentha piperita, Cinnamomum zeylanicum, Melaleuca alternifolia and Eucalyptus globulus were proved to be most effective against the fungus Trichosporon ovoides.
\end{abstract}

Key words: Essential oils, Piedra hair infection, antifungal activity.

\section{INTRODUCTION}

Piedra, is an asymptomatic fungal infection of the hair shaft, resulting in the formation of nodules of different hardness on the infected hair. The conditions caused are considered as superficial mycoses because the hosts do not produce any immune-reactive response $(3,4)$. Two varieties of Piedra may be seen, one called Black Piedra and the other White Piedra. Black Piedra is typically caused by the fungi Piedrae hortae and Trichosporon ovoides. It is mostly found

*Corresponding Author. Mailing address: Department of Botany, SGRR (PG) College, Pathribagh, Dehradun, 248001.; E-mail: depttbot@ymail.com / seema.sx@gmail.com 
in tropical countries like South America and South East Asia (18). On the other hand, White Piedra, caused by other Trichosporon species, occurs in semitropical and temperate countries. Trichosporon genus is subdivided into six distinct human pathogenic species of which Trichosporon ovoides, Trichosporon inkin, Trichosporon mucoides and Trichosporon asahii are linked to White Piedra (2). Black Piedra is characterized by the presence of firm black, hard, gritty nodules which are actually a mass of fungus cells on the hair shaft. They cause a disintegration and breakage in the hair fibre. These stone hard black nodules are usually localized to the scalp, but may also be seen on hairs of the beard, moustache and pubic hair with the fungal activity limited to the cuticle (7). White Piedra is characterized by white to light brown nodules that may surround the entire hair shaft. Nodules are soft and the fungal mass can easily be detached from the hair. Encapsulated arthroconidia or blastoconidia with polygonal appearance are observed under direct microscopic examination $(3,4,10,14,17,27)$. The fungus Trichosporon ovoides which is involved in causing both types of Piedras is found in soil, lake water and plants and can occasionally be seen as normal flora of the human skin and mouth. Trichosporon, in particular has also been considered urophilic due to its ability to occupy strongly acidic localisations when colonizing pubic hair and its capacity to utilize urea and uric acid. The fact that they select hair as substratum may be due to their keratinophillic affinity $(3,4)$.

Piedra are defined as superficial mycosis because they neither invade living tissue nor provoke an immune response by the host $(3,4)$. Infection does not seem related to personal hygiene or exposure to an infected person but it is suggested that its spread can be prevented by not sharing brushes, combs and other hair accessories (9).

The classical and most effective therapy for White and Black Piedra has been and still is the cutting and shaving of the hairs, a treatment recommended by the American Academy of Dermatology (6). Topical antifungals are also recommended and the application of Clotrimazole cream alone (26) or after shampooing with Ketoconazole proved to be good therapeutic treatment for White Piedra (13).

As a result of immense use of these antifungal drugs used for the treatment of infectious disease, the resistance of the organisms increased (1). This situation forced researchers to search for new antimicrobial substance from various sources including medicinal plants (1). Essential oils have been traditionally used for treatment of infections and diseases all over the world for centuries (22). In recent years there has been extensive research to explore and determine the antimicrobial activity of essential oils.

In the present study, screening of some essential oils was undertaken to find out if these can be used as effective fungicides to control skin and hair infections and whether they can be used as a substitute for drugs of chemical origin.

\section{MATERIALS AND METHODS}

Procurement and Maintenance of Cultures: The culture of the fungal species Trichosporon ovoides (NCYC No.2796) was procured from National Collection of Yeasts Culture, Norwich, UK for the study and was maintained on selective media i.e. Yeast Malt Agar (Supplied from Central drug house Pvt. LTD. New. Delhi). At optimum temperature of $25^{\circ} \mathrm{C}$ the fungus shows full mycelial growth and sporulation after $48 \mathrm{hrs}$. of incubation in petriplates of $15 \mathrm{~mm}$ diameter.

Collection of Plant material: 25 aromatic plants belonging to 15 families were collected from different regions of Dehradun District. The plant specimens were submitted to the Division of Botany, FRI, Dehradun for identification. The seeds, roots and leaves of plants were dried and ground to semi-powered state.

Extraction procedure: The seeds, roots and leaves for oil were dried and ground to semi-powdered state. The air dried aerial parts (250 gm) were hydro distilled in a Clevenger apparatus for 5 hours in accordance with the British pharmacopoeia. The aqueous phase was extracted with dichloromethane. The organic phase was dried with sodium 
sulphate, filtered and the solvent evaporated until dryness by air-drying. The fractions obtained were combined into calibrated flasks and evaporated to dryness. The oils were solubilized in $20 \%$ DMSO (dimethyl suphoxide) when used for antimycotic activity. The oils were stored in sealed glass bottles in a refrigerator at $4^{0} \mathrm{C}$ until required.

\section{Antifungal Assays}

Agar Well diffusion Assay: Preliminary analysis of antifungal activity was conducted using Agar well diffusion assay as described by Garcia et al.2002 (8). First of all, fungal inoculum was prepared in Tween 80 saline solution and incubated for 1 hour. Then $1 \mathrm{ml}$ of this solution was homogeneously inoculated into Petriplates containing Sabouraud Dextrose Agar (SDA) (Supplied from Himedia Laboratories Private. Ltd Mumbai) medium and kept for solidification. After solidification, wells of $6 \mathrm{~mm}$ diameter were punctured in the culture medium using sterile cork borer. A fixed volume $(100 \mu \mathrm{l} / \mathrm{ml})$ in $20 \%$ DMSO of respective essential oil was loaded in the wells using sterilized micropipettes. DMSO was used as a negative control and Nystatin $(100 \mathrm{mg} / \mathrm{disc})$ and Imidazole $(50 \mathrm{mg} / \mathrm{disc})$ were used as positive control. Plates were incubated for $2-3$ days at $25^{\circ} \mathrm{C}$. Zone of Inhibition in mm was determined after $48 \mathrm{hrs}$ for different oils.

\section{Minimum Inhibitory Concentration}

Tube Dilution Asssay: The MIC and MFC values of essential oils were determined using two fold broth microdilution to prepare oil concentration of 200, 100, 50, 25, 12.5, $6.2,3.1,1.55$ and $0.75 \mu 1 / \mathrm{ml} .20 \%$ DMSO was used as a solvent for essential oil. $1 \mathrm{ml}$ of each oil was added to test tubes containing $1 \mathrm{ml}$ of sterile SD broth. The tubes were then incubated with $1 \mathrm{ml}$ of the fungal suspension and incubated at $25^{\circ} \mathrm{C}$ for 2 days. Nystatin $\mathrm{B}$ and Imidazole were used as positive controls for the fungus. The MIC values were determined macroscopically after $48 \mathrm{hrs}$ of incubation in comparison with the growth and sterility controls (5). SDA plates were divided into eight different sections and labelled with the different concentrations on the plates. The plates were incubated for $48 \mathrm{hrs}$ at $25^{\circ} \mathrm{C}$ after which the MFC were recorded. Three replicates were used for each essential oil concentration and controls against the fungus (20).

Gas Chromatography: The GC analysis of five most effective essential oils was carried out using a GC apparatus (Agilent Technologies, $6890 \mathrm{~N}$ ). The analysis was performed with a DB -5 column $(0.32 \mathrm{~mm} \times 30 \mathrm{~m})$. Nitrogen gas was used as carrier gas with a flow rate of $1 \mathrm{ml} / \mathrm{min}$. The column was raised from $60^{\circ} \mathrm{C}$ to $220{ }^{\circ} \mathrm{C}$ at a rate of $3{ }^{\circ} \mathrm{C} / \mathrm{min}$. The identification of oil components was based on their retention time with available literature values.

\section{RESULTS}

The result in Fig. 1 shows the antifungal properties of twenty five essential oils against Trichosporon ovoides through Agar Well Diffusion Assay. The highest inhibitory effect was recorded with oil of Cinnamomum zeylanicum $(50 \mathrm{~mm}$, inhibition zone) followed by Cymbopogon winterians (45mm), Melaleuca alternifolia (45mm), Citrus bergamia (40mm), Eucalyptus globulus (36mm), Mentha piperita (35mm), Abelmoschus moschatus (32mm), Ocimum basilicum (30mm), Citrus aurantium (30 mm), Jasminum officinale (30 $\mathrm{mm})$, Citrus limon (28mm), Citrus aurantifolia (23mm), Boswellia carterii (20mm), Palargonium graveolens (20 $\mathrm{mm})$, Cymbopogon flexuosus (15mm), Salvia sclarea (13mm), Cedrus atlantica (11mm). Pogostemon patchouli, Juniperus communis, Commiphora myrrha, Cyperus scariosus, Rosa damascene, Veteveria zizanioides, Zingiber officinalis and Trachyspermum ammi oils showed no inhibition. The growth of $T$. ovoides was thus affected by seventeen out of twenty five essential oils. On the other hand, the remaining eight oils were unable to cause any inhibitory effect. Out of Seventeen oils which affected the growth of $T$. ovoides, C. zeylanicum, C. winterians, M. alternifolia, C. bergamia, E. globulus and M. piperita exerted higher inhibitory effects in comparison to $C$. flexuosus, S. sclarea and C. atlantica which showed lower anti- 
yeast activity against $T$. ovoides. Antifungal synthetic drugs Nystatin B and Imidazole showed inhibition zones of $30 \mathrm{~mm}$ and $25 \mathrm{~mm}$ respectively. Most of the essential oils used in the study showed better zones of inhibitions compared to that produced by the antifungal synthetic drugs. The inhibitory effect of 25 essential oils against $T$. ovoides was studied. The effect of different concentrations of 25 essential oils belonging to different families was tested against the yeast species. All the concentrations of the essential oils inhibited the yeast species with varying degree of sensitivity. The MIC and MFC of the screened plants against $T$. ovoides is shown in Table 1. Essential oil of Eucalyptus globulus showed the best activity against the yeast $T$. ovoides with MIC value of $0.75 \mu \mathrm{l} / \mathrm{ml}$ and MFC value of $1.55 \mu 1 / \mathrm{ml}$ followed by the essential oil of Cinnamomum zeylanicum exhibiting MIC value of $1.55 \mu 1 / \mathrm{ml}$ and MFC value of 3.1. $\mu \mathrm{l} / \mathrm{ml}$. C. limon, C. winterians, $S$. sclarea, P. graveolens, J. officinale showed similar MIC value of $3.1 \mu \mathrm{l} / \mathrm{ml}$ with MFC value of $6.2 . \mu \mathrm{l} / \mathrm{ml}$. C. aurantifolia showed MIC value of $6.2 \mu \mathrm{l} / \mathrm{ml}$ with MFC value of $12.5 \mu \mathrm{l} / \mathrm{ml}$. M. piperita, C. bergamia, J. communis inhibited the growth of the yeast at a concentration of $12.5 \mu \mathrm{l} / \mathrm{ml}$ with MFC at $25 \mu \mathrm{l}$ $/ \mathrm{ml}$ followed by O. basilicum, C. flexuosus, M. alternifolia, C. aurantium, P. patchouli, A. moschatus, and B. carterii at an MIC value of $25 \mu \mathrm{l} / \mathrm{ml}$ and MFC value of $50 \mu \mathrm{l} / \mathrm{ml}$. MIC value detected in the case of T. ammi \& C. myrrha was $50 \mu 1$ $/ \mathrm{ml}$ and MFC value was $100 \mu \mathrm{l} / \mathrm{ml}$. MIC determined in case of oil of Z. officinalis and C. scariosus was $100 \mu \mathrm{l} / \mathrm{ml}$ with MFC value of $200 \mu \mathrm{l} / \mathrm{ml}$. C. atlantica and $R$. damascene showed MIC at $200 \mu \mathrm{l} / \mathrm{ml}$ with MFC value of $300 \mu \mathrm{l} / \mathrm{ml}$. Antifungal drug Nystatin B inhibited the visible growth at a concentration of $3.1 \mathrm{mg} / \mathrm{ml}$ and exhibited MFC of $6.2 \mathrm{mg} / \mathrm{ml}$ whereas Imidazole exhibited MIC at $6.2 \mathrm{mg} / \mathrm{ml}$ and MFC of $12.5 \mathrm{mg} / \mathrm{ml}$. (Fig. 4). Fig. 1 shows inhibition zones produced by different oils against $T$. ovoides through Agar well diffusion assay and MIC, MFC of different essential oils are shown in Table 1 with Fig. 2 and Fig 3.

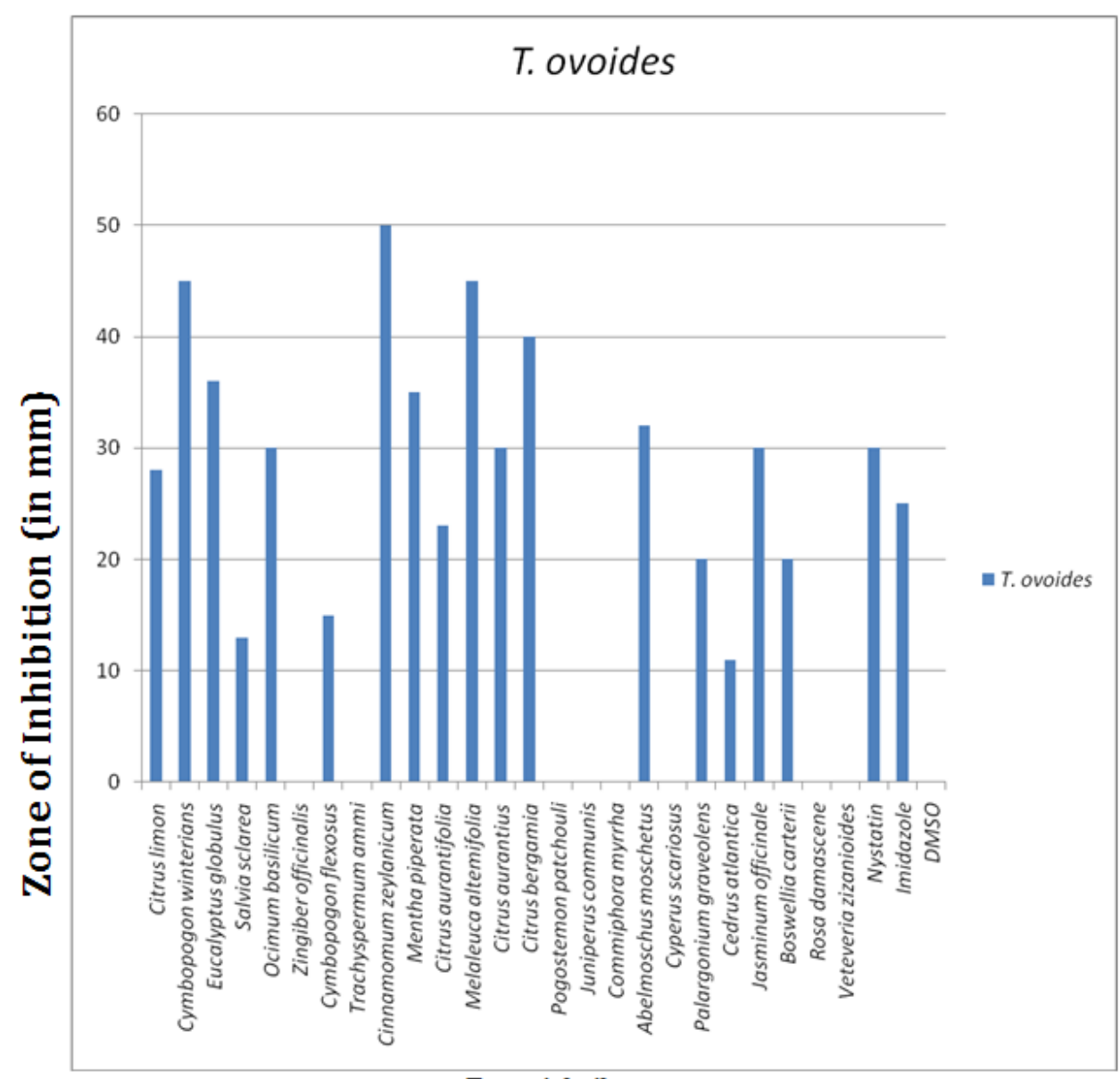


Table 1. MIC and MFC of Essential Oils against $T$. ovoides

\begin{tabular}{|c|c|c|c|c|c|}
\hline Botanicanl Names & Local names & Family & Parts used & MIC (in $\mu \mathrm{l} / \mathrm{ml}$ ) & MFC (in $\mu \mathrm{l} / \mathrm{ml}$ ) \\
\hline Juniperus communis & Juniper & Cupressaceae & Berries and Twig & 12.5 & 25 \\
\hline Commiphora myrrha & Myrrh & Burseraceae & Gum, Resin, sap & 50 & 100 \\
\hline Zingiber officinalis & Ginger & Zingiberaceae & Root \& Rhizome & 3.1 & 6.2 \\
\hline Boswellia carterii & Frankincense & Burseraceae & Resin & 25 & 50 \\
\hline Eucalyptus globulus & Eucalyptus & Myrtaceae & Leaves, Fruit, sap & 0.75 & 1.55 \\
\hline Citrus aurantifolia & Lime & Rutaceae & Leaves, Fruit \& peel & 6.2 & 12.5 \\
\hline Citrus aurantium & Orange & Rutaceae & Fruit \& Peel & 25 & 50 \\
\hline Cinnamomum zeylanicum & Cinnamon & Lauraceae & Bark, leaves & 1.55 & 3.1 \\
\hline Cedrus atlantica & Cedarwood & Pinaceae & Twig \&Leaf & 200 & 400 \\
\hline Citrus limon & Lemon & Rutaceae & Fruit, Peel, Seeds & 3.1 & 6.2 \\
\hline Melaleuca alternifolia & Teatree & Myrtaceae & Leaves & 25 & 50 \\
\hline Cyperus scariosus & Nagarmotha & Cyperaceae & Roots & 100 & 200 \\
\hline Jasminum officinale & Jasmine & Oleaceae & Flower & 3.1 & 6.2 \\
\hline Pogostemon patchouli & Patchouli & Labiatae & Leaves & 25 & 50 \\
\hline Citrus bergamia & Bergamot & Rutaceae & Flower and Fruit & 12.5 & 25 \\
\hline Ocimum basilicum & Basil & Lamiaceae & Leaves and stem & 25 & 50 \\
\hline Palargonium graveolens & Geranium & Geraniaceae & Leaves and flowers & 3.1 & 6.2 \\
\hline Salvia sclarea & Clarysage & Labiatae & leaves & 3.1 & 6.2 \\
\hline Mentha piperita & Peppermint & Labiatae & leaves & 12.5 & 25 \\
\hline Abelmoschus moschatus & Musk & Malvaceae & seeds & 25 & 50 \\
\hline Cymbopogon winterians & Citronella & Poaceae & Leaves, Grass & 3.1 & 6.2 \\
\hline Trachyspermum ammi & Ajowain & Apiaceae & seeds & 50 & 100 \\
\hline Cymbopogon flexuosus & Lemongrass & Poaceae & Leaves and stem & 25 & 50 \\
\hline Vetiveria zizanoides & Khas & Poaceae & root & 100 & 200 \\
\hline Rosa damascene & Rose & Rosaceae & Flower and leaves & 200 & 300 \\
\hline 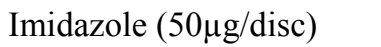 & - & - & - & 12.5 & 25 \\
\hline Nystatin B $(100 \mu \mathrm{g} / \mathrm{disc})$ & - & - & - & 6.2 & 12.5 \\
\hline
\end{tabular}
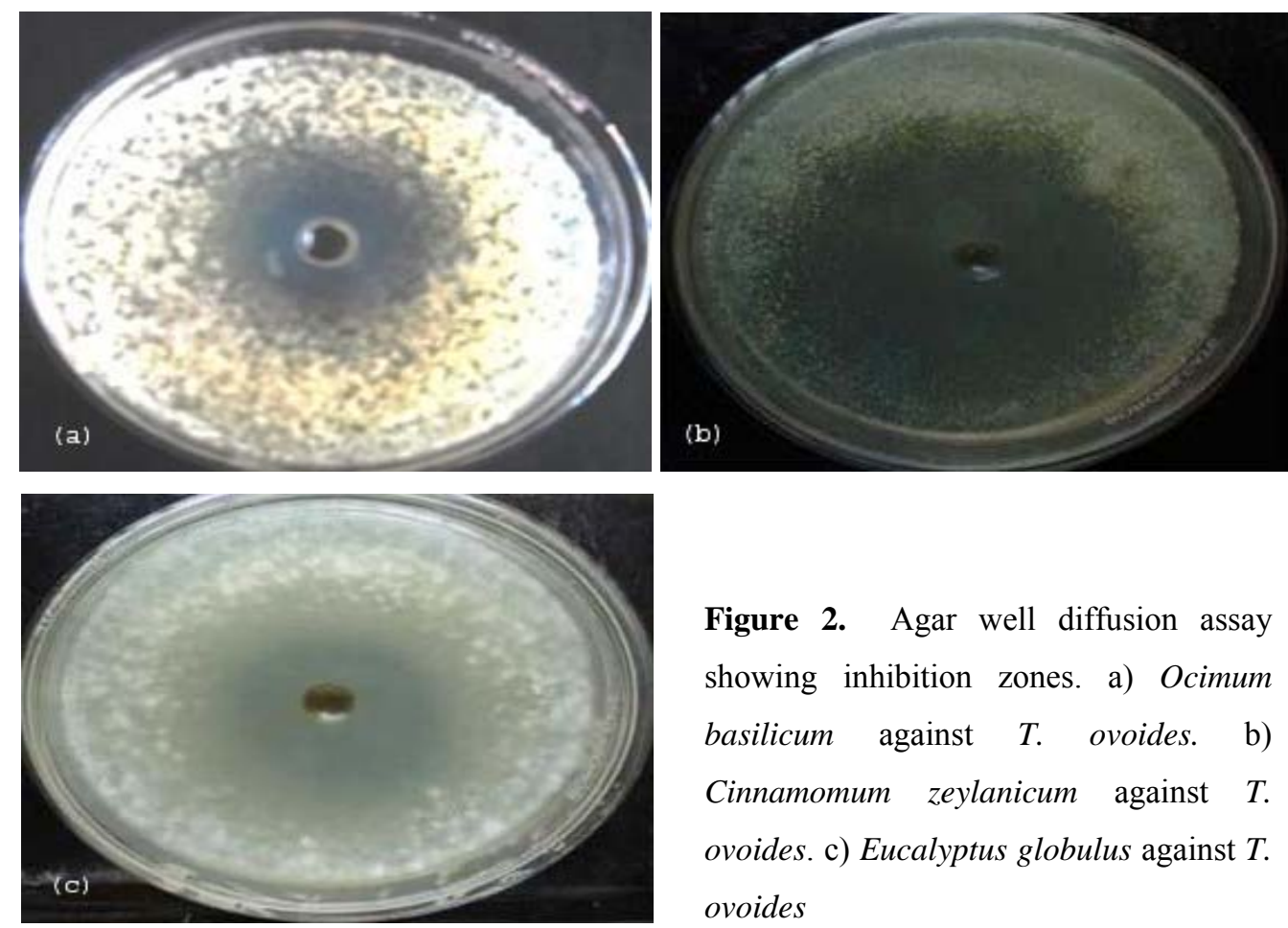

Figure 2. Agar well diffusion assay showing inhibition zones. a) Ocimum basilicum against $T$. ovoides. b) Cinnamomum zeylanicum against $T$. ovoides. c) Eucalyptus globulus against $T$. ovoides 

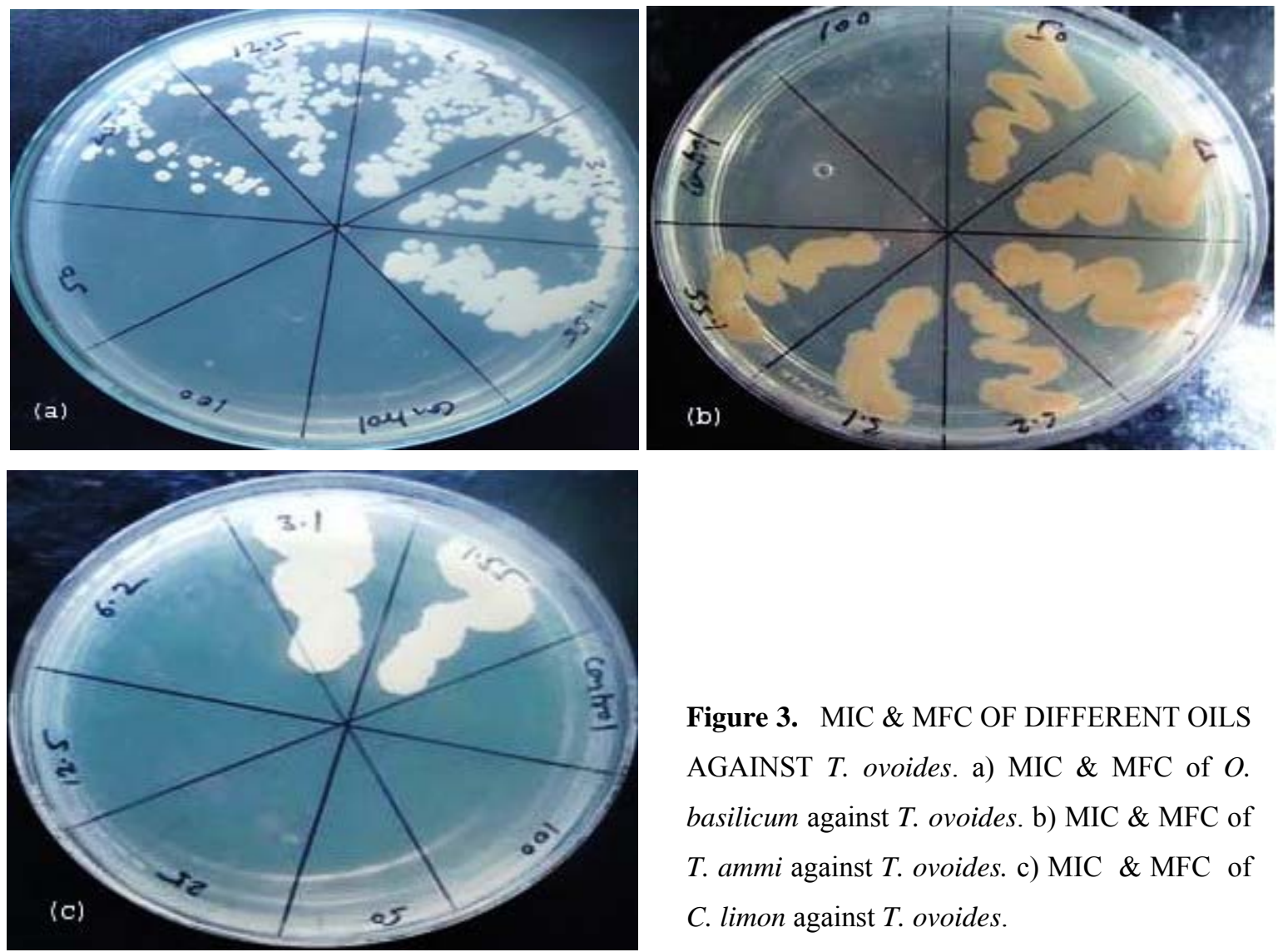

Figure 3. MIC \& MFC OF DIFFERENT OILS AGAINST T. ovoides. a) MIC \& MFC of $O$. basilicum against $T$. ovoides. b) MIC \& MFC of T. ammi against T. ovoides. c) MIC \& MFC of C. limon against $T$. ovoides.
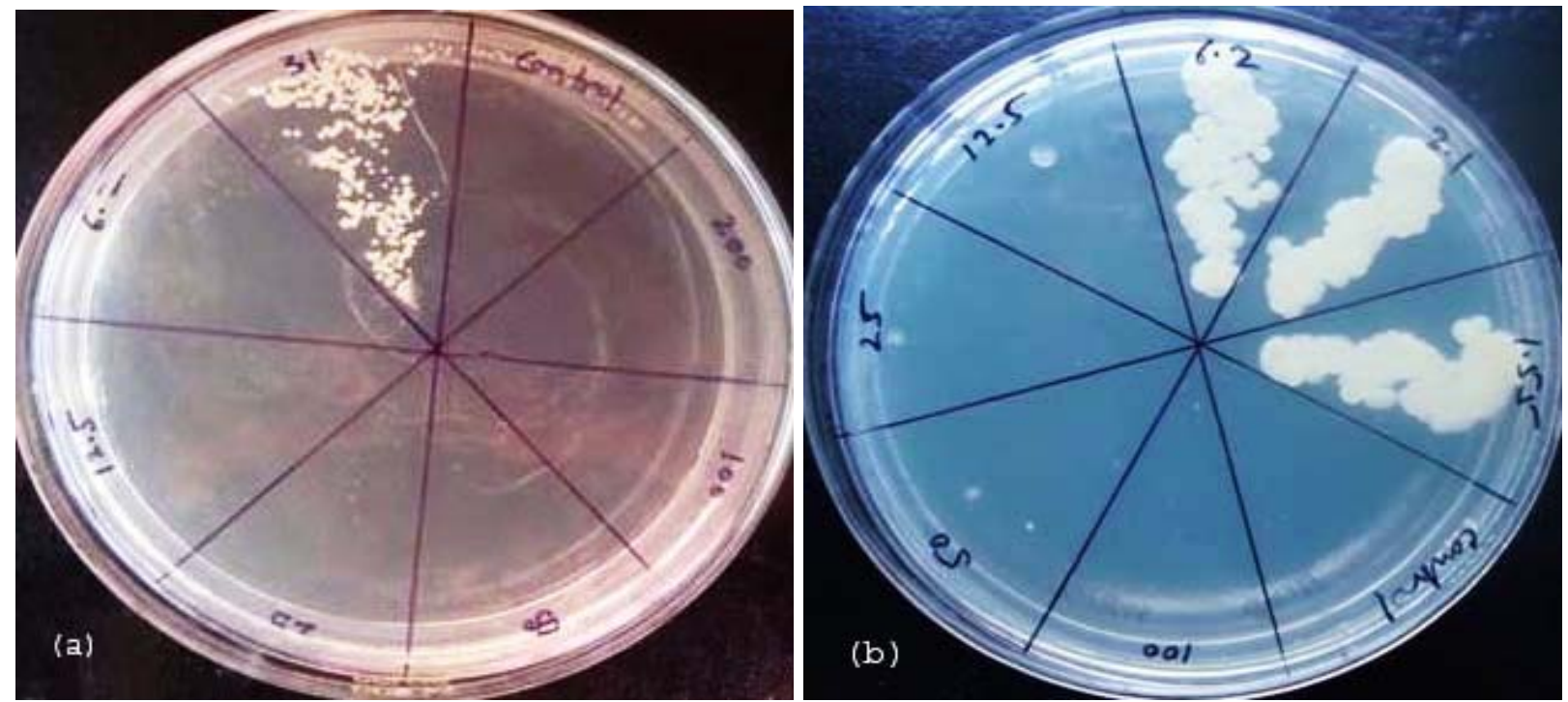

Figure 4. MIC \& MFC of Antifungal drugs against T. ovoides. a) MIC \& MFC of Nystatin B against T. ovoides. b) MIC \& MFC of Imidazole against $T$. ovoides 
GC analysis: The identification of oil constituents was carried out by GC analysis of oil samples. Five oils viz. Cinnamon, Citronella, Peppermint, Eucalyptus and Tea tree were analysed and the constituents present in each oil was identified. All the five oils were highly effective against Trichosporon ovoides showing large inhibition zones.
The major constituent of Cinnamon oil was identified as Eugenol (60.68\%), that of Citronella as Geraniol (39.60\%), Tea tree as Terpinen-4-ol (50.94\%), Peppermint as Isomenthol (66.94\%) and Eucalyptus as 1,8 cineole $(20.75 \%)$. Other constituents of the essential oils are given in Table 2.

Table 2. GC Analysis of essential oils constituents. List of Constituents

\begin{tabular}{ccl}
\hline S. No & Essential Oils & \multicolumn{1}{c}{ Oils Constituents (\%) } \\
\hline 1 & Citronella & Geraniol (39.60\%), Citronellal (18.21\%), Citronellol (10.28\%), E-citral (5.94\%), Geranyl acetate \\
& & $(5.78 \%)$, z-citral (3.50\%), Citronellyl acetate $(2.07) \&$ Linalool (1.71\%) \\
2 & Tea Tree & Terpinen-4-ol (50.94\%), 1,8-cineole (10.11\%) \& $\alpha$-pinene $(2.21 \%)$ \\
3 & Peppermint & Iso-menthol (66.94\%), iso-menthyl acetate (3.12\%) \& p-menthone (2.19\%) \\
4 & Cinnamon & Eugenol (60.68\%) \& $\alpha$-phellandrene $(27.66 \%)$ \\
5 & Eucalyptus & 1,8 -cineole (20.75\%), $\alpha$-pinene (18.50\%), $\alpha$-phellandrene (14.29\%) \& $\alpha$-terpineol acetate (2.32\%) \\
\hline
\end{tabular}

\section{DISCUSSION}

To our knowledge this study appears to be the first that actually looked at the antifungal effect of essential oils against Piedra hair infection. The inhibitory effects of twenty five essential oils against the Trichosporon ovoides were studied.

The traditional use of plants as medicines provide the basis for indicating which essential oils and plant oils may be useful for specific medical conditions. Historically, many plant oils and extracts, such as tea tree, myrrh and clove, have been used as topical antiseptics, or have been reported to have antimicrobial properties (15). There are earlier reports determining the fungitoxic spectrum of these essential oils against other pathogenic fungi. The essential oils have been evaluated for antifungal activities from Palmarosa, Citronella and Lemon grass against four human pathogenic fungi, namely Microsporum gypseum, Aspergillus niger, Candida albicans and Sporothrix schenckii (24). Various publications have documented the antimicrobial activity of essential oils and plant extracts including rosemary, peppermint, bay, basil, tea tree, celery seed and fennel. All the oils tested exhibited different degrees of antifungal activity against Aspergillus fumigatus \& Aspergillus niger (12, 16, 19, 23).The antifungal activity of essential oils obtained from Cinnamon, Oregano,
Mexican Oregano, Thyme, and Ginger essential oils showed inhibition against Fluconazole resistant and Fluconazole susceptible candida species (21). Bergamot oil was found to be active against clinical isolates of some dermatophytes namely as Trichophyton spp., Epidermophyton spp., and Microsporum spp (25). Melaleuca alternifolia was found to be active against Cladosporium, Alternaria, Aspergillus, Fusarium (11). It is important to investigate scientifically those plants which have been used in traditional medicines as potential sources of novel antimicrobial compounds. Data from our study has confirmed the antimicrobial potential of plant products, particularly the anti-yeast effect of 25 essential oils noted by MIC values and total inhibition of the growth of the assayed dematiaceous yeast strains. Moreover, our findings show that these essential oils could arise as promising alternative antimicrobial compounds to be inserted in pharmaceutical formulations used to treat mycoses of different clinical severities caused by dematiaceous yeasts.

\section{ACKNOWLEDGEMENTS}

Thanks are due to Professor V.A. Bourai, Principal, SGRR (PG) College, Dehradun for providing us the lab facility; NCYC, for the procurement of yeast culture; HOD of 
Department of Botany \& Forest Research Institute, Dehradun for the Identification of Plant species.

\section{REFERENCES}

1. Bauer, A.W.; Kirby, W.M.; Sherris, J.C.; and Turck, M. (1996). Antibiotic susceptibility testing by standardized single disc method. Am. J. Clin. Pathol. 44, 493-496.

2. Chagas-Neto, T.C.; Chaves, G.M.; Colombo, A.L. (2008). Update on the genus Trichosporon. Mycopathologia. 166, 121-132.

3. de Hoog, G. S; Guarro, J. (Eds.) (1995). Atlas of Clinical Fungi, Baarn, Holland, CentralsbureauvoorSchimmelcultures.

4. de Hoog, G.S.; Gueho, E. Agents of White Piedra, Black Piedra and Tinea nigra. In: Collier L. Ballows A, Sussman M(Eds.) (1998). Topiey \& Wilson's Microbiology and microbial infections. Vol. 4: Medical mycology. Ajello L, Hay RJ(Eds.) London, Publ Arnold, 191-197.

5. Demarsh, P. L.; Gagnon, R. C.; Hetzberg, R. P. and Jaworski, D. D. (2001). Methods of screening for antimicrobial compounds. Smithkline Boccham Corporation. Publ. World Intellectual Property Organization (WIPO).

6. Drake, L.A.; Dinehart, S.M.; Farmer, E. R. (1996).Guidelines of care for superficial mycotic infections of the skin: Piedra. J. Am. Acad. Dermatol. 34, 122-124.

7. Figueras, M. J.; Guarro. J.; Zaror, L. (1996). New findings in black piedra infection. Br J Dermatol. 135(1), 157-8.

8. Garcia, S.; Araiza, M.; Gomez, M.; Heredia, N. (2002). Inhibition of growth, enterotoxin and spore production of Clostridium perfringes by extracts of medicinal plants. J. Food Prot. 65, 1667-1669.

9. Gip, L. (1994). Black Piedra: the first case treated with terbinafine (Lamisil). Br J Dermatol. 130, 26-8.

10. Graham, J.H.; Barroso-Tobila, C. (1971). Dermal pathology of superficial infection. In: Baker RD (Ed).Human Infection with Fungi, Actinomycetes and Algae. New York. Springer. 359-371.

11. Hammer, K.A.; Carson, C.F; and Riley, T.V. (2002). In vitro activity of Melaleuca alternifolia (Tea tree) oil against dermatophytes and other filamentous fungi. J. of Anti. Chemo. 50, 195-199.

12. Hili, P.C. S. Evans and Veness, R.G. (1997). Antimicrobial action of essential oils: the effect of dimethyl sulfoxide on the activity of Cinnamon oil. Letters in Appl. Microbiol. 24, 269-275.
13. Kubec, K.; Dvorak, R.; Alsaleh, Q.A. (1998). Trichosporosis (white piedra) in Kuwait. Int. J. Dermatol.37, 186-187.

14. Kwon-Chung, K.J.; Bennet, J.E. (1992). Medical Mycology. Philadelphia, Lea \& Febiger, 183-190.

15. Lawless, J. (1995). The Illustrated Encyclopaedia of Essential oils. Shaftesbury, UK: Element Books Ltd.

16. Lis-Balchin, M.; and Deans, S.G. (1997). Bioactivity of selected plant essential oils against Listeria monocytogenes. J. Appl. Bacteriol. 82, 759-762.

17. Mackinnon, J.E.; Schouten, G.B. (1942). Investigaciones sobre las enfermedades de los cabellos denominadas Piedra. Arch Soc Biol Montevideo. 10, 227-266.

18. Magalhaes, A.R.; Mondino, S.S.B.; Silva, M.; Nishikawa, M.M. (2008). Morphological and Biochemical Characterization of the aetiological agents of white Piedra. Mem. Inst. Oswaldocruz. 103(8), 786-790.

19. Morris, J.A.; Khettry, A. and Seitz, E. W. (1979). Antimicrobial activity of aroma chemicals and essential oils. J. Am. Oil Chemists' Soc. 56, 595603.

20. NCCLS (2000). Methods for dilution antimicrobial susceptibility tests for bacteria that grow aerobically. Approved standard fifth edition. NCCLS document. M7-A5.NCCLS: Wayne, PA, USA.

21. Pozzati, P.; Scheid, L.A.; Spader, T.B.; Atayde, M.L.; Santurio, J.M.; Alves, S.H.(2008). In vitro activity of essential oils extracted from plants used as spices against fluconazole-resistant and fluconazole-susceptible Candida spp. Can. J. Microbiol. 54, 950-956.

22. Rios, J.L.; Recio, M.C. (2005). Medicinal plants and antimicrobial activity. J. of Ethnopharmacol.100, 80-84.

23. Ross, S.A.; El-Keltawi, N.E. and Megalla, S.E. (1980). Antimicrobial activity of some Egyptian aromatic plants. Fitoterapia. 51, 201-205.

24. Saikia, D.; Khanuja, S.P.S.; Kahol, A.P.; Gupta, S.C.; Kumar, S. (2001). Comparative antifungal activity of essential oils and constituents from three distinct genotypes of Cymbopogon spp. Current Science. 80, 12641266.

25. Sanguinetti, M.; Posteraro, B.;Romano, L.; Battaglia, F.; Lopizzo, T.; Carolis, E. De.(2007). In vitro activity of Citrus bergamia (bergamot) oil against clinical isolates of dermatophytes.J Anti. Chemo.59, 305-308.

26. Selim, M.M.; Kubec, K.; Baghli, NMAAl. (1988). Trichosporosis of the hairs of the scalp in Kuwait. Mycoses. 31, 198-200.

27. Taplin, D.; Rebell, G. (1984). Piedra In: Demis J, McGuire J(Eds) Clinical Dermatology, New York, Harper \& Row Publishers. 1-4, 1-7. 